\title{
Factors influencing the quality of healthcare services in Indian hospitals: A systematic review
}

\author{
Ajayan Kamalasanan ${ }^{1 *}$, Gurumoorthy $\mathbf{S}^{2}$, Arun Vijay Subbarayalu ${ }^{3}$ \\ ${ }^{\mathbf{1}}$ Research Scholar, ${ }^{\mathbf{2}}$ Associate Professor, ${ }^{\mathbf{3}}$ Assistant Professor, Dept. of Business Administration, ${ }^{\mathbf{1}}$ Annamalai University, Tamil Nadu \& \\ ${ }^{1}$ Lecturer, Dept. of Measurements \& Evaluation, Deanship of Quality \& Academic Accreditation, Imam Abdulrahman Bin Faisal \\ University, Dammam, Saudi Arabia, ${ }^{2}$ Annamalai University, Tamil Nadu, ${ }^{3}$ Deanship of Quality \& Academic Accreditation, Imam \\ Abdulrahman Bin Faisal University, Dammam, Saudi Arabia
}

\section{*Corresponding Author: Ajayan Kamalasanan}

Email: ajayvkl@hotmail.com

\begin{abstract}
Introduction: Quality management culture is still a novel concept which is slowly inculcating into the healthcare organizations across India. In order to induct quality management in India, the quality council established the National Accreditation Board for Hospital and Healthcare Providers (NABH). Those who are involved in providing healthcare should be well aware of the quality aspects and its importance to make sure that the patients receive the best quality care in an economical and efficient way. It is vital to keep track of the growing needs and requirements in terms of quality management and patient safety.

Aim: This study aims to review and analyze the factors influencing quality management in the Indian healthcare organizations, to identify the research gap.

Materials and Methods: The literature for the review was obtained from the "PubMed" and Google Scholar with Indian affiliation. The review covered the healthcare quality management studies from January 1998 till December 2018, which yielded 82 articles and the careful scrutiny reduced the number to 59 .

Findings \& Conclusion: Several studies prevail on quality of healthcare management, but the various factors of quality management were not addressed fully. The major research gap was identified under the areas of planning \& documentation, employee participation, policies $\&$ procedures, quality \& patient safety, quality process and its outcome, perceived effect in quality improvement, training and development opportunities, and the future plans of quality management. This research gap illustrates that there exists a lacunae, which is to be filled through more studies, focusing the different quality aspects.
\end{abstract}

Keywords: Quality, Healthcare Services, Hospitals, India, Systematic Review.

\section{Introduction}

Quality management process focusing on healthcare organizations emerged in the United States of America, incepted through the medical audits in 1900s. Gradually the audits transformed into quality standards, which later materializes into the current quality assurance processes. This transformation was guided through the formation of the Joint Commission on Accreditation of Healthcare Organizations, which is an independent not-for profit organization formed in the US during the year 1951. To assess the quality standards and to accredit the hospitals in India, the quality council of India established the National Accreditation Board for Hospital and Healthcare Providers (NABH). However, quality management culture is still a novel concept in the healthcare organizations in India, which is slowly inculcating into the health sector across the nation.

Healthcare quality management is getting more and more complicated when the hospitals integrate different departments and its related multiple specialties, which leads to change in the existing policies, procedures and organizational climate of healthcare institutions. As the multiple specialties and service areas increases, there are probabilities of human errors or medical errors, which may be scooped out of the system to eliminate the possible slips. The phrase "medical errors" is an umbrella term for all inaccuracies that occur within the health care system, including mishandled surgeries, diagnostic errors, equipment failures, and medication errors. ${ }^{1-2}$ Human errors in medical settings are natural, but it should be identified at the earliest and has to be reported to avoid repetition of the same. This may be made possible by providing the healthcare professionals with confidence and legal support for error disclosure. This raises serious concerns and indicates that physicians may not be aware of the new legal protections afforded for error disclosure and if the health care system is to realize the benefits of error reporting systems, greater education of physicians regarding their legal protections may be needed. ${ }^{3}$

Hence, all those who are involved in providing healthcare service should be well aware of the quality aspects and its importance to make sure that the patients receive the best quality care in an economical and efficient way. Mostly training is focused on the care of individual patients with specific conditions and little attention and time goes to educating healthcare professionals on wider professional issues such as how patient care depends on contributions of colleagues from other disciplines; working in teams; organizational behavior and change; and clinical audit or continuous quality improvement. ${ }^{4}$ Therefore, there is an urgent need to reduce healthcare errors; eliminate barriers, which impede progress in this regard, including widespread misunderstanding about why healthcare errors occur, the prevailing culture of "name and blame" surrounding these events, lack of user-friendly error-reporting mechanisms, and fear of litigation, if errors are acknowledged and reported. ${ }^{5}$ In this context it is vital to keep track of the growing needs and 
requirements in terms of quality management and patient safety.

This illustrates that there are several reasons to develop and implement quality management systems in the healthcare settings, which include improving efficiency, accountability and eliminating errors for better clinical outcomes to meet patient care. Improvements in treatment quality and reducing the rate of adverse events make up the largest portion of the benefits of quality management. ${ }^{6}$ Further, it is crucial to meet the requirements of patients to exceed their satisfaction by complying with the quality standards. Based on the exploration of previous studies, the authors identified only six reviews, focusing on quality management aspects in the Indian context, but among those reviews only three were dealing with the aspects of quality management. Even though there are quite a few studies in India looking into the different aspects of quality management, all available literature is not systematically reviewed to identify the pros and cons while implementing quality management practices in the healthcare settings. This review is in the context of a need for having a fool proof quality systems and hence, this study is a review and analysis of the prevailing quality management aspects in the Indian healthcare organizations, which may help to identify the research gap.

\section{Materials and Methods}

The literature for the review was obtained from "PubMed", which is an interface to look for the database maintained by the United State's National Library of Medicine (NLM) at the National Institute of Health. The database accesses primarily the MEDLINE references of life science and biomedical topics, covering more than 12 million citations. The search was carried out on December 2018 with key words as "healthcare" under medical subject headings (mesh terms), "quality" as title word and "India" as affiliation; focusing on quality management in healthcare with Indian affiliation, provided 82 articles across the period from January 1998 till December 2018. Careful physical scrutiny of the above listed articles further reduced the number of quality management studies into 42 , since only those articles met the inclusion criteria. In addition to the 42 articles identified from PubMed, the authors searched the Google Scholar for literature which are not listed in PubMed and identified 17 more quality management articles by physical scrutiny, which were incorporated into the review, yielded a total of 59 healthcare quality management studies.

\section{Inclusion/Exclusion criteria}

All study designs, including reviews, cross sectional, case control, descriptive studies and interventional studies were considered for the review with special focus on the factors influencing the implementation of healthcare quality management practices in Indian hospitals. However, studies conducted outside the country with Indian affiliation is excluded from the review.

\section{Selection of Articles for the Review}

Authors used a three tire assessment system for the selection of listed articles. The first author carried out the search and initial scrutiny of articles and the second author independently evaluated the articles for eligibility and significance for the systematic review. Disagreements between the first and the second author were settled with discussion on the relevance of disputed articles with the third author.

The initial selection was on the basis of quality related publications in healthcare sector with Indian affiliations, conducted on the above stated period. These results generated 82 publications, which consists of quality management articles, clinical studies and few studies which were not related with this review. Hence, the authors conducted a manual scrutiny of articles to classify the studies into the above stated three groups; those studies related with quality management with a broader overview of the quality aspects in healthcare services $(n=42)$, clinical studies specific to clinical aspects or diseases $(n=24)$ and irrelevant studies to the area of this review $(n=16)$. While categorizing, the authors also identified six systematic reviews, of which only three of the reviews were addressing the factors influencing the implementation of healthcare quality management practices in Indian hospitals. The publications related with healthcare quality management was searched and identified in Google Scholar $(n=17)$ were also incorporated into the review. Fig. 1 below illustrates the identification and classification of articles:

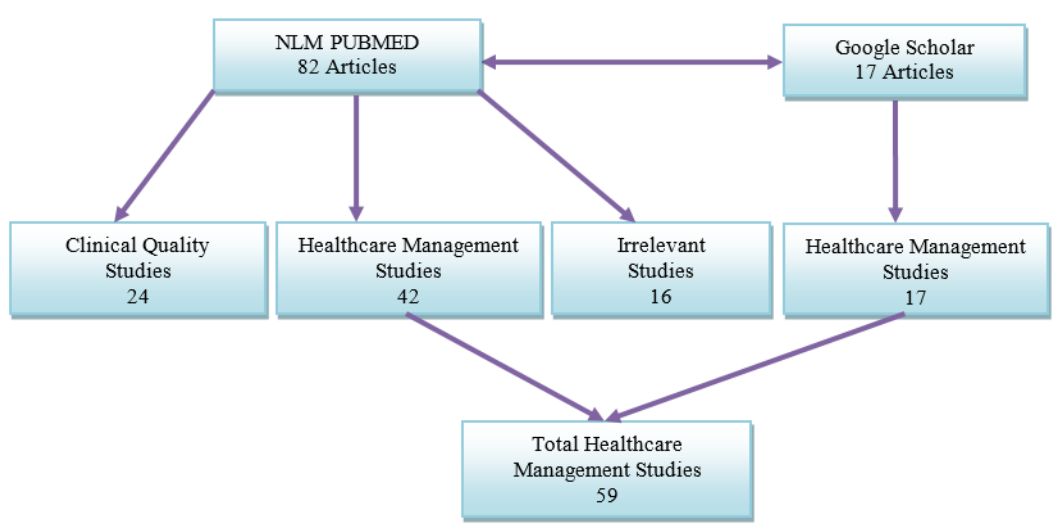

Fig. 1: Classification of research publications based on literature search 


\section{Article Extraction and Analysis}

All the identified studies were listed out with details like journal name, period of study, title, author information, relevancy of the study with this review, objective, design or methodology, its findings and conclusion of the study. Based on the information gathered from the review of articles, the authors developed following dimensions as found to be influencing the quality of services offered in Indian Hospitals: (a) Planning \& Documentation (b) Employee Participation in Quality Management Activities (c) Existence of Policies/ Procedures/ Guidelines (d) Quality \& Patient Safety Management (e) Evaluation of the Process and its Outcome (f) Perceived Effect of Quality Improvement (g) Training and Development Opportunities (h) Future Plans and (i) Other studies, which cannot be categorized under the above stated dimensions (table 1). Specific quality indicators/variables were identified under each dimension and the articles were categorized accordingly. The methodology used by different researches was explored, which is also categorized under different quality dimensions and its related variables (table 2). Sorting of articles was based on the period of publication and analyzed it for relevancy with this study. All the published articles in the last twenty years were reviewed for its findings and the developments happened. Among the identified articles, the first publication was observed to be in November 1998 and the last publication was on November 2018.

Table 1: Categorization of articles based on different dimensions and variables

\begin{tabular}{|c|c|c|c|}
\hline Dimensions & Variables & PUBMED & Google Scholar \\
\hline A. Planning \& Documentation & $\begin{array}{l}\text { Awareness of mission statement, existence of } \\
\text { documentation plan, quality \& safety manual, quality } \\
\text { management systems, well-defined operational plan, } \\
\text { involvement in planning, roles, responsibilities and } \\
\text { tasks are stated }\end{array}$ & 2 & 0 \\
\hline $\begin{array}{l}\text { B. Employee Participation in Quality } \\
\text { Management Activities }\end{array}$ & $\begin{array}{l}\text { Quality management activities, reporting system, } \\
\text { employee adherence to the work plan, employee } \\
\text { satisfaction surveys, involvement in internal quality } \\
\text { audit(s). }\end{array}$ & 2 & 0 \\
\hline $\begin{array}{l}\text { C. Existence of Policies/ Procedures/ } \\
\text { Guidelines }\end{array}$ & $\begin{array}{l}\text { Existence of updated policies/ guidelines for clinical } \\
\text { procedures, policies/ guidelines for administrative } \\
\text { procedures, involvement in preparation of } \\
\text { policies/guidelines, adherence to policies and } \\
\text { procedural manual and responsibilities to execute the } \\
\text { policies and procedures. }\end{array}$ & 2 & 0 \\
\hline $\begin{array}{l}\text { D. Quality \& Patient Safety } \\
\text { Management }\end{array}$ & $\begin{array}{l}\text { Internal medical audit/ accreditation/ peer review } \\
\text { within the group, individual patient care, external } \\
\text { audit, awareness of relevant quality tools, system to } \\
\text { track safety related issues, reporting of adverse events } \\
\text { and action, risk management, patients' feedback, } \\
\text { system for monitoring complaints. }\end{array}$ & 14 & 10 \\
\hline $\begin{array}{l}\text { E. Evaluation of the Process and its } \\
\text { Outcome }\end{array}$ & $\begin{array}{l}\text { Data used from clinical indicators, complications } \\
\text { registration data, complaints registration, patient } \\
\text { survey, employee survey, incident reporting system, } \\
\text { outcome of internal review/ audit, outcome of } \\
\text { external review/ audit. } \\
\text { Indicators of patient outcome, quality of life, health } \\
\text { condition, patient access time for } 1^{\text {st }} \text { appointment, } \\
\text { duration of total care process, waiting time, staff } \\
\text { turnover }\end{array}$ & 5 & 4 \\
\hline $\begin{array}{l}\text { F. Perceived Effect of Quality } \\
\text { Improvement }\end{array}$ & $\begin{array}{l}\text { Patient satisfaction, staff satisfaction, management } \\
\text { controllability, brand image, patient treatment/care } \\
\text { processes, cost saving, number and nature of the } \\
\text { regulations \& procedures. }\end{array}$ & 11 & 3 \\
\hline $\begin{array}{l}\text { G. Training and Development } \\
\text { Opportunities }\end{array}$ & $\begin{array}{l}\text { Need continuous training programs, imparts } \\
\text { necessary training on quality, encourages to } \\
\text { participate in training programs, skill development } \\
\text { on-the-job training is required, gained knowledge } \\
\text { through the training programs. }\end{array}$ & 3 & 0 \\
\hline H. Future Plans & $\begin{array}{l}\text { Installing quality projects, adherence to the quality } \\
\text { cycle (PDCA), regular patient surveys, internal } \\
\text { quality assessment, external quality assessment, } \\
\text { redesign of patient care process }\end{array}$ & 1 & 0 \\
\hline I. $\quad$ Other studies & - & 2 & 0 \\
\hline \multicolumn{2}{|l|}{ Total } & 42 & 17 \\
\hline
\end{tabular}


Table 2: Methodology used by different studies

\begin{tabular}{|c|c|c|c|c|}
\hline Dimensions & Variables & 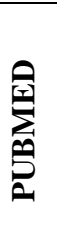 & 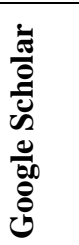 & Methodology Used \\
\hline $\begin{array}{ll}\text { A. } & \text { Planning \& } \\
\text { Documentation }\end{array}$ & $\begin{array}{l}\text { Awareness of mission statement, } \\
\text { existence of documentation plan, } \\
\text { quality and safety manual, quality } \\
\text { management systems, well-defined } \\
\text { operational plan, involvement in } \\
\text { planning, roles, responsibilities and } \\
\text { tasks are stated }\end{array}$ & 2 & 0 & $\begin{array}{l}\text { 1. Retrospective Observational Study } \\
\text { with pre-intervention and post- } \\
\text { intervention method } \\
\text { 2. Assessed the coverage and quality of } \\
\text { immunization services }\end{array}$ \\
\hline $\begin{array}{l}\text { B. Employee } \\
\text { Participation in } \\
\text { Quality Management } \\
\text { Activities }\end{array}$ & $\begin{array}{l}\text { Quality management activities, } \\
\text { reporting system, employee adherence } \\
\text { to the work plan, employee } \\
\text { satisfaction surveys, involvement in } \\
\text { internal quality audit(s). }\end{array}$ & 2 & 0 & $\begin{array}{l}\text { 1. Service quality } \\
\text { 2. Factor analysis to find underlying } \\
\text { relationships between the survey } \\
\text { items }\end{array}$ \\
\hline $\begin{array}{l}\text { C. Existence of Policies/ } \\
\text { Procedures/ } \\
\text { Guidelines }\end{array}$ & $\begin{array}{l}\text { Existence of updated policies/ } \\
\text { guidelines for clinical procedures, } \\
\text { policies/ guidelines for administrative } \\
\text { procedures, involvement in } \\
\text { preparation of policies/guidelines, } \\
\text { adherence to policies and procedural } \\
\text { manual and responsibilities to execute } \\
\text { the policies and procedures. }\end{array}$ & 2 & 0 & $\begin{array}{l}\text { 1. An extensive in-depth healthcare } \\
\text { quality literature review } \\
\text { 2. Addressing shortfalls of previous } \\
\text { agendas by articulating the critical } \\
\text { role of quality improvement in the } \\
\text { Sustainable Development Goal era. }\end{array}$ \\
\hline $\begin{array}{l}\text { D. Quality \& Patient } \\
\text { Safety Management }\end{array}$ & $\begin{array}{l}\text { Internal medical audit/ accreditation/ } \\
\text { peer review within the group, } \\
\text { individual patient care, external audit, } \\
\text { awareness of relevant quality tools, } \\
\text { system to track safety related issues, } \\
\text { reporting of adverse events and action, } \\
\text { risk management, patients' feedback, } \\
\text { system for monitoring complaints. }\end{array}$ & 14 & 10 & 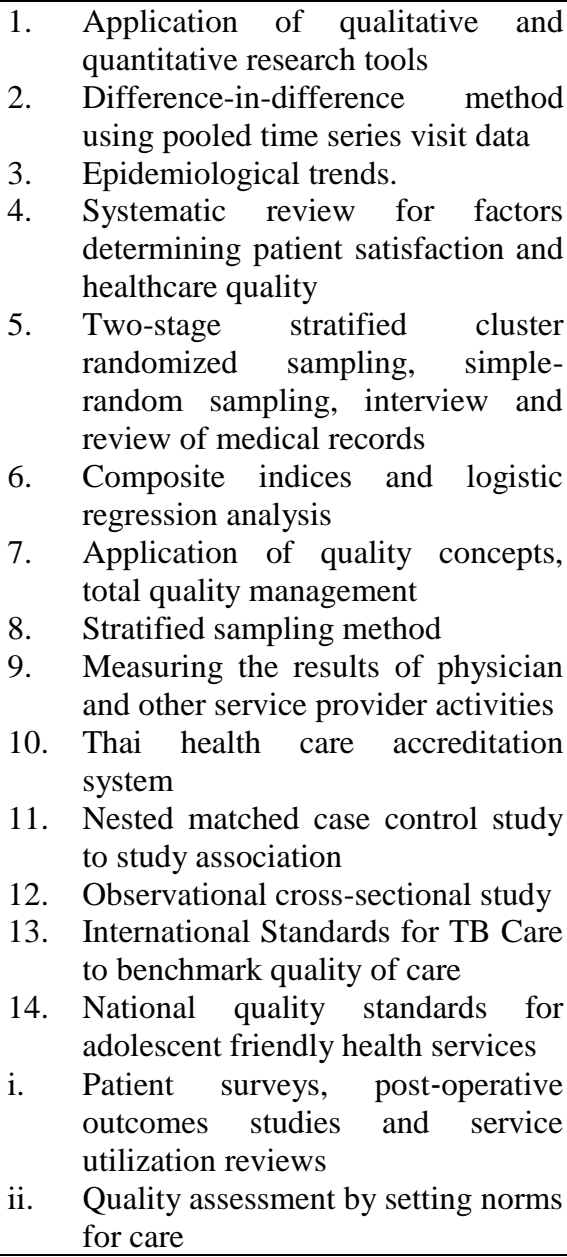 \\
\hline
\end{tabular}




\begin{tabular}{|c|c|c|c|c|}
\hline & & & & $\begin{array}{ll}\text { iii. } & \text { Working paper } \\
\text { iv. SERVQUAL questionnaire survey } & \begin{array}{l}\text { Sung Service Quality Model } \\
\text { using }\end{array} \\
\text { v. } & \begin{array}{l}\text { Case study using logical framework } \\
\text { analysis to project planning for } \\
\text { managing quality }\end{array} \\
\text { vi. } & \begin{array}{l}\text { Assessment of access and choice } \\
\text { equalities/inequalities }\end{array} \\
\text { vii. } & \begin{array}{l}\text { Malcom Baldrige National Quality } \\
\text { Award (MBNQA) criteria in-depth } \\
\text { interviews }\end{array} \\
\text { viii. } & \begin{array}{l}\text { Medical vignettes and direct } \\
\text { observation }\end{array} \\
\text { ix. } & \begin{array}{l}\text { Direct observation of infrastructure } \\
\text { x. Technical aspects of quality, process } \\
\text { and outcome }\end{array} \\
\end{array}$ \\
\hline $\begin{array}{l}\text { E. Evaluation of the } \\
\text { Process and its } \\
\text { Outcome }\end{array}$ & $\begin{array}{l}\text { Data used from clinical indicators, } \\
\text { complications registration data, } \\
\text { complaints registration, patient } \\
\text { survey, employee survey, incident } \\
\text { reporting system, outcome of internal } \\
\text { review/ audit, outcome of external } \\
\text { review/ audit. } \\
\text { Indicators of patient outcome, quality } \\
\text { of life, health condition, patient access } \\
\text { time for } 1^{\text {st }} \text { appointment, duration of } \\
\text { total care process, waiting time, staff } \\
\text { turnover }\end{array}$ & 5 & 4 & 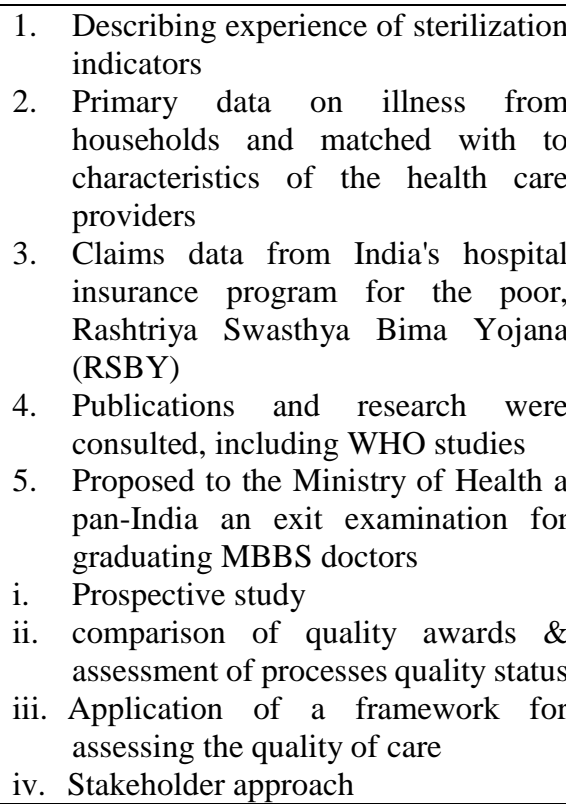 \\
\hline $\begin{array}{ll}\text { F. } & \text { Perceived Effect of } \\
\text { Quality Improvement }\end{array}$ & $\begin{array}{l}\text { Patient satisfaction, staff satisfaction, } \\
\text { management controllability, brand } \\
\text { image, patient treatment/care } \\
\text { processes, cost saving, number and } \\
\text { nature of the regulations \& } \\
\text { procedures. }\end{array}$ & 11 & 3 & $\begin{array}{l}\text { 1. Cross-sectional survey of health } \\
\text { facilities and patients at clinics } \\
\text { 2. A 20-item scale administered to the } \\
\text { users } \\
\text { 3. Two-stage cluster sampling for a } \\
\text { community-based, cross-sectional } \\
\text { study } \\
\text { 4. A cross-sectional hospital-based } \\
\text { study } \\
\text { 5. Questionnaire survey, Descriptive } \\
\text { statistics, factor analysis, regression } \\
\text { and correlation statistics were } \\
\text { employed } \\
\text { 6. A conceptual framework is proposed } \\
\text { to measure hospital service quality } \\
\text { 7. narrative review of published } \\
\text { comparative clinical trials that } \\
\text { evaluated efficacy or effectiveness } \\
\text { of clinic-based CVD prevention and } \\
\text { management quality improvement } \\
\text { interventions in LMICs } \\
\text { 8. Exploratory study } \\
\text { 9. Descriptive study }\end{array}$ \\
\hline
\end{tabular}




\begin{tabular}{|l|l|l|l|l|}
\hline & & & & $\begin{array}{l}\text { 10. A structured questionnaire was used to } \\
\text { obtain data from teaching, public } \\
\text { and corporate hospital patients } \\
\text { 11. Prospective observational study } \\
\text { i. Questionnaire survey } \\
\text { ii. Case study } \\
\text { iii. Prospective study }\end{array}$ \\
\hline $\begin{array}{l}\text { G. Training and } \\
\text { Development } \\
\text { Opportunities }\end{array}$ & $\begin{array}{l}\text { Need continuous training programs, } \\
\text { imparts necessary training on quality, } \\
\text { encourages to participate in training } \\
\text { programs, skill development on-the- } \\
\text { job training is required, gained } \\
\text { knowledge through the training } \\
\text { programs. }\end{array}$ & 3 & 0 & $\begin{array}{l}\text { 1. Post training application of semi- } \\
\text { structured focus group discussions } \\
\text { Counseling and training } \\
\text { Onsite supervision \& training of } \\
\text { Clinics using National Aids Control } \\
\text { Organization's Monitoring Tool for } \\
\text { recording and reporting }\end{array}$ \\
\hline H. Future Plans & $\begin{array}{l}\text { Installing quality projects, adherence } \\
\text { to the quality cycle (PDCA), regular } \\
\text { patient surveys, internal quality } \\
\text { assessment, external quality } \\
\text { assessment, redesign of patient care } \\
\text { process }\end{array}$ & 1 & 0 & $\begin{array}{l}\text { 1. Inception of the Practice Innovation } \\
\text { and Clinical Excellence registry }\end{array}$ \\
\hline I. Other studies & - & 2 & 0 & \begin{tabular}{l}
$1 . \quad \begin{array}{l}\text { Survey of consecutive patients } \\
\text { Guidelines and standards monitors } \\
\text { outcomes and conducts operations } \\
\text { research }\end{array}$ \\
\hline Total
\end{tabular} \\
\hline
\end{tabular}

\section{Discussion}

Hospitals and the healthcare system in India are now more conscious on the quality of services that they provide to their patients and are looking ahead to improve the services in all aspects. The quality culture is slowly, but steadily inculcated into our healthcare system, since the patients started choosing hospitals that maintain a certain level of quality standards and services. This may be due to the increased awareness and perception of patients on the quality and safety aspects, which may be more prevalent in the urban regions of India. Perception of patients on the quality of services is a key performance indicator of healthcare management. Results of a study suggest that patient experience is generally correlated with the quality of care provided. ${ }^{7}$ The study is in this context, to systematically review the literature to analyze and elucidate an exact picture on the factors influencing the implementation of quality management practices and the research developments, prevailing in the Indian healthcare settings.

The authors explored the literature to study the prevailing quality practices followed in health sector over the period of last 20 years and we noticed that there were studies on the application of qualitative and quantitative aspects of planning, managing and appraising the quality of care. In order to explore the studies which were carried out in the Indian healthcare system, we categorized the identified articles based on nine different dimensions and the related variables (Table 1). The dimensions includes, (a) planning and documentation, (b) employee participation in quality management activities, (c) existence of policies/ procedures/ guidelines, (d) quality and patient safety management, (e) evaluation of the process and its outcome, (f) perceived effect of quality improvement, $(\mathrm{g})$ opinion of the employees on training and development opportunities and finally (h) the future plans for improvement. Further, we made one more category for (i) other studies, which are not falling under any of the above dimensions. To be specific, there were 59 research studies exclusively focusing on healthcare management, including three review articles.

After categorization of the studies into different dimensions, we observed the attempts made by the healthcare research fraternity, exploring different management aspects (Table 1) with 2 studies identified under Planning \& Documentation, 2 studies in Employee Participation in Quality Management Activities, 2 studies on the Existence of Policies/ Procedures/ Guidelines, 24 studies in Quality and Patient Safety Management, 9 studies on Evaluation of the Process and its Outcome, 14 studies in the area of perceived effect of quality improvement methods, 3 articles in Training and Development Opportunities, 1 study on future plans for improvement and finally 2 Other Studies which cannot be categorized under the eight listed categories.

The above stated studies were assessed for the conclusion they arrived at and it is observed that majority of the studies fell under the dimension Quality and Patient Safety Management. The identified articles $(n=24)$ in this dimension focused on quality improvement, research, application of quality concepts, relationship of physical environment quality and interaction quality, continuous quality improvement, quality of the referral services, prescription based on quality index scores and the usage of government run health facilities, successful model for highquality equitable healthcare, need for quality management systems, also discusses critical areas of management concerns, identified gap in service quality, introduction of an integrated quality management tool, evidence on inequalities 
of access to healthcare, illustrates measurement of quality performance, perception of doctors and the low standards provided on quality of care in low-income countries, scope for improvement of quality of services of private practitioners and the need for the approach 'quality as a construct' for the healthcare managers. ${ }^{8-31}$ But, there were no studies on the good practices of internal or external audit/accreditation, application of quality management tools, systems to track patient safety, risk management and reporting.

However, among the 14 studies on Perceived Effect of Quality Improvement, there was a standalone article, which describes some of the reasons for bridging the gap between research and practice, and offers suggestions to fill the chasm between researchers and implementers of low-middle and high income countries. ${ }^{32}$ Quality managers in healthcare always strive hard to translate research into practice; hence, such studies may help the professionals to implement the research findings for quality improvement. The remaining studies in this category confer to the aspects of patient satisfaction, need of measuring perceived service quality, availability and quality care at public hospitals and implementation of quality care and patient loyalty. Among those studies, four of them were exclusively looking into the aspects of hospital service quality from the patient perceptive. ${ }^{33-45}$ But, there were no studies on staff satisfaction, brand image, healthcare processes and cost saving.

The review identified nine studies on evaluation of healthcare management process and its outcome, ${ }^{46-54}$ which discusses on ensuring quality in sterilization process, socioeconomic status of patients and quality of care, efforts to raise quality of care, need for improving the quality of patient data, quality standards in the medical profession, underestimation of mortality in Indian patients compared to Acute Physiology \& Chronic Health Evaluation scores of USA, development of an instrument to assess patients perception of quality, quality of maternal health services, and obstacles in hospital accreditation. Research on issues of registration data, employee perception, incident reporting system, outcome of review, indicators of patient outcome, patient access time, duration of care, waiting time, staff turnover etc were not addressed yet.

There were only two studies in the dimension, existence of polices/procedures, ${ }^{55-56}$ where the studies suggest the need of an integrated quality model to maintain quality of service for the advantage of the patients. The second article recommends the need of quality policy formulation, its implementation and learning at national level. However, there are no studies on the status of policies/guidelines for clinical procedures, administrative procedures, involvement of employees on preparation of policies/guidelines, adherence of the system to the policies and procedures. This was followed by two studies under the dimension employee participation in quality management activities, ${ }^{57-58}$ discussing on the insignificance of nonclinical support staff on patient satisfaction, while the second study points out that the study helps the managers focus on their policy and prepare their efforts in a way to attain customer satisfaction. But, there were no studies on employee participation in quality management activities, reporting system, work plan, employee satisfaction and internal quality audits. Two studies were identified in the dimension, planning and documentation ${ }^{59-60}$ which illustrates the weakness in quality management is due to lack of forecasting appropriate strategy for patient appointment and follow-up. However, no studies were there on employee awareness of mission, documentation plan, quality manuals, quality management systems and the roles and responsibilities.

Further analysis of literature demonstrates three articles on employee opinion on training and development opportunities. ${ }^{61-63}$ The studies points out classroom based training of nurses may differ from that of physician attitude, impact of intensive training programs on HIV counselors and the importance of supportive supervision, which is practice oriented, uninterrupted and as an interactive method of training. But, there are no studies discussing on skill development and need of on-the-job training. Nevertheless, a standardized patient study in India discusses about the lack of proper training of healthcare providers, where they suggests an urgent need to measure the quality of healthcare services to improve the quality of medical education and continuing education programs. ${ }^{64}$ Regarding this topic, a study conducted in US on the issues of training in quality and safety describes the systems approach to training and it examines innovative training and education techniques that are already gaining acceptance in healthcare. ${ }^{65}$ While carrying out the categorization of studies into eight dimensions, we also noticed a couple of studies which are not exactly falling under the above stated categories. The studies discussed on matters related with quality of communication with cancer patients and its relation with simple changes in the organization of clinics and physician education. The second study on quality management in sexually transmitted infection illustrates targeted HIV intervention can be bought to scale and can be standardized, if provided with adequate capacity building support. ${ }^{66-67}$

The different studies we identified used various methodologies to carry out the research (table 2), which includes three reviews. Among the different methodologies three of the studies used a cross-sectional mode of study. Along with different other methods, surveys, case study, criterion based interviews, direct observation, working paper, questionnaire based studies, prospective study and stakeholder approach methodology were also used by different authors. One among the study used a novel approach of using a combined application of qualitative and quantitative research tools drawn from the social sciences and health sciences for planning and evaluating quality of care in child health programs. ${ }^{8}$ 


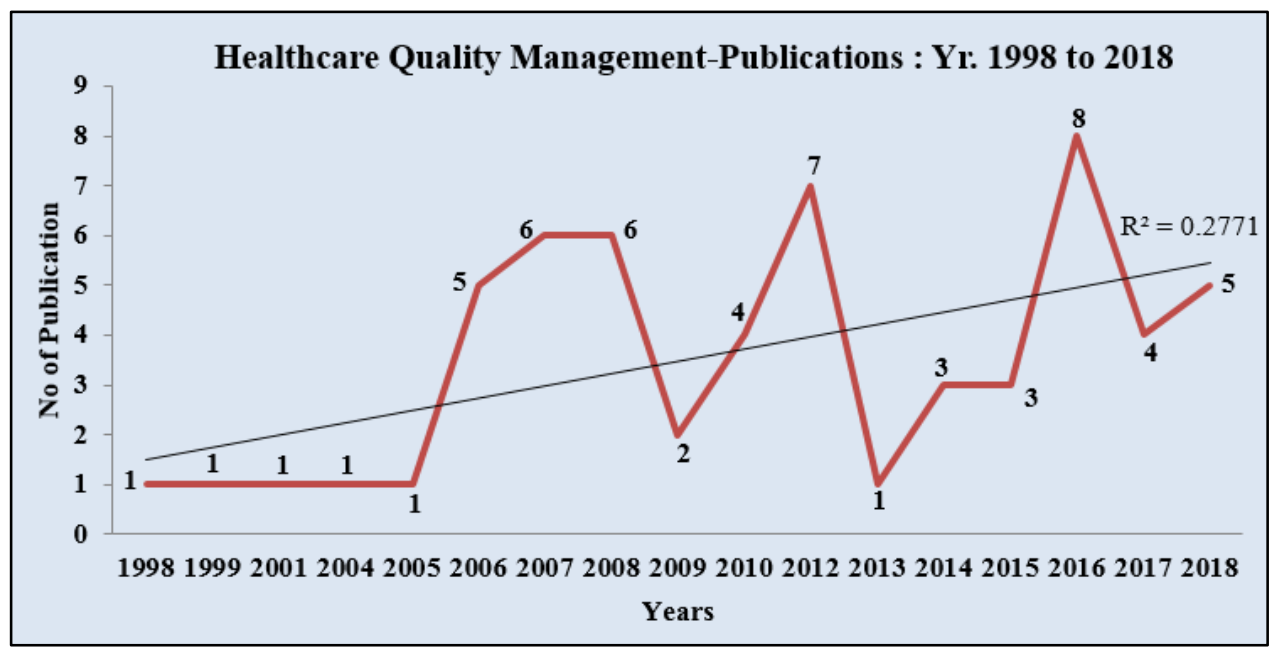

Fig. 2: Healthcare quality management publications-Year 1998 to 2018

We observed a varied number of publications $(n=59)$ during the last 20 year period (1998-2018). Figure 2 illustrates that the quality management studies were bare minimum during the period from 1998 till 2005, which may be because the quality management culture was slowly instilling into the healthcare system during this period. However, majority of publications occurred during the period from 2006 to $2012(\mathrm{n}-30)$ and thereafter during the period 1998 to 2009 the number of studies dropped and diminished to 7 articles. Nevertheless, the number of research increased to 17 studies during 2016 to 2018 , which may further increase in the coming years.

Even though there are serious studies on quality management, research gap still prevails on various quality management aspects. It is evident that there is barely one study on future quality management plans and three studies in the area of training $\&$ development during the above stated period. Some of the aspects under the dimension, 'Planning and Documentation' namely, documentation plan, quality systems, stakeholder involvement in planning and roles and areas of responsibilities are yet to be addressed. When we explored the category under 'Employee Participation and Quality Management', it is observed that there are only two studies, both discuss about patient or customer satisfaction. But, there is no research on the different aspects of this category namely, quality management activity, incident reporting, employee adherence to work plan, employee satisfaction surveys and involvement of employees in the internal quality audit. Similarly, the area under the category 'Policies and Procedures' also lack studies on the existence of such policies, the degree of adherence to the policies and its execution are not addressed at all. The area of 'Quality \& Patient Safety Management' has the maximum number of publications; however this category also lacks studies on specific aspects like audit/ accreditation/ peer review, system to track safety related issues, reporting of adverse events and action, risk management, patients' feedback and system for monitoring complaints. Another category, 'Evaluation of the Process and its Outcome' also is in short of research, especially on the aspects of different quality management data and the indicators of patient outcome. Even though there are studies on 'Perceived Effect of Quality Improvement', still there is research gap in the aspects of staff satisfaction, management controllability, brand image, patient care processes, cost saving and number and nature of the regulations \& procedures. Further, a wide research gap still prevails in the category "Opinion on Training and Development Opportunities" and "Future Quality Management Plans".

\section{Conclusion}

The systematic review elucidates the fact that several studies prevails on quality of healthcare management in India, which varied across the review period from 1998 to 2018. The research attempt on quality management was inducted in the year 1998, but such studies were negligible in number until 2005. Even though there are studies on different aspects of quality management, the various factors of quality management were not addressed fully. The major research gap was identified under the areas of planning \& documentation, employee participation in quality management activities, policies \& procedures, some areas in quality \& patient safety management, evaluation of the quality process and its outcome, issues like perceived effect in quality improvement, like employee satisfaction and their opinion on training and development opportunities, and the future plans of quality management. This research gap illustrates that there exists a lacunae, which is to be filled with further studies, focusing the different quality aspects of management.

\section{Conflict of Interest: None.}

\section{Reference}

1. Lassetter JH, Warnick ML. Medical errors, drug-related problems, and medication errors: a literature review on quality of care and cost issues. J Nurs Care Qual 2003;18(3):175-81.

2. Foucar E. Error: an obstacle in the journey from quackery to quality. Pathologica 2001;93(5):605-7.

3. Howard J, Levy F, Mareiniss DP, Patch M, Craven CK, McCarthy M, Epstein-Peterson ZD, Wong V, Pronovost P. 
New legal protections for reporting patient errors under the Patient Safety and Quality Improvement Act: a review of the medical literature and analysis. J Patient Saf 2010;6(3):147-52.

4. Dodwad SS. Quality management in healthcare. Indian $J$ Public Health 2013;57(3):138-43.

5. Kizer KW. Patient safety: a call to action: a consensus statement from the National Quality Forum. Med Gen Med 2001;3(2):10.

6. Schroeder-Printzen I. Costs and benefits of quality management. Urologe A 2014;53(1):15-20.

7. Stein SM, Day M, Karia R, Hutzler L, Bosco JA. Patients' perceptions of care are associated with quality of hospital care: a survey of 4605 hospitals. Am J Med Qual 2015;30(4):382-8.

8. Kanani S. Towards quality of care in child health programmes: a challenge for the partnership in health and social sciences. Soc Sci Med 1998;47(9):1223-30.

9. Dipankar Rao K, Peters DH. Health Econ 2007;16(8):799-813. Quality improvement and its impact on the use and equality of outpatient health services in India. Health Econ 2007;16(8):799-813.

10. Samy AA. National Workshop on "Is integration a leap forward?--Implications of integration on quality care in leprosy", Mumbai. Lepr Rev 2007;78(3):306-8.

11. Naidu A. Factors affecting patient satisfaction and healthcare quality. Int J Health Care Qual Assur 2009;22(4):366-81.

12. Dhar RS, Nagpal J, Bhargava V, Sachdeva A, Bhartia A. Quality of care, maternal attitude and common physician practices across the socio-economic spectrum: a community survey. Arch Gynecol Obstet 2010;282(3):245-54.

13. Anand S, Sinha RK. Quality differentials and reproductive health service utilisation determinants in India. Int $J$ Health Care Qual Assur 2010;23(8):718-29.

14. Virdi MS. Quality considerations in dental education in India. J Dent Educ 2012;76(3):372-6.

15. Chahal H, Kumari N. Service quality and performance in the public health-care sector. Health Mark Q 2012;29(3):181-205.

16. Bansal CP. Improving quality of pediatric care in India a call for action. Indian Pediatr 2013;50(3):269-70.

17. Mate KS, Rooney AL, Supachutikul A, Gyani G. Accreditation as a path to achieving universal quality health coverage. Global Health 2014;10:68.

18. Chaturvedi S, Randive B, Diwan V, De Costa A. Quality of obstetric referral services in India's JSY cash transfer programme for institutional births: a study from Madhya Pradesh province. PLoS One 2014;9(5).

19. Suthar JV, Patel VJ. Assessment of quality of prescribing in patients of hypertension at primary and secondary health care facilities using the Prescription Quality Index (PQI) tool. Indian J Pharmacol 2014;46(5):480-4.

20. Satyanarayana S, Subbaraman R, Shete P, Gore G, Das J, Cattamanchi A, Mayer K, Menzies D, Harries AD, Hopewell P, Pai M. Quality of tuberculosis care in India: a systematic review. Int J Tuberc Lung Dis 2015;19(7):751-63.

21. Chandra-Mouli V, Chatterjee S, Bose K. Do efforts to standardize, assess and improve the quality of health service provision to adolescents by government-run health services in low and middle income countries, lead to improvements in service-quality and service-utilization by adolescents? Reprod Health 2016;13:10.

22. Ráz Samandari Sharon Kleefield Jim Hammel Mehul Mehta Robert Crone. Privately funded quality health care in India: a sustainable and equitable model. Int J Qual Health Care 2001;13(4):283-8.

23. Khan, Faisal; Khan, Humera Quality Management in the Healthcare Industry. Decision (0304-0941). 2004;31(2):136-67

24. K.V. Ramani, Dileep Mavalankar. Health system in India: opportunities and challenges for improvements. J Health Organ Manag 2006;20(6).
25. Rohini R, Mahadevappa B. Service quality in Bangalore hospitals - an empirical study. J Serv Res 2006;6(1):59-68,7076,78-79,81-84.

26. Prasanta Kumar Dey, Seetharaman Hariharan. Integrated approach to healthcare quality management: a case study", The TQM Magazine, 2006;18(6):583-605.

27. Jishnu Das and Jeffrey Hammer Location, Location, Location: Residence, Wealth, and the Quality of Medical Care in Delhi, India. Health Affairs 2007;26(3):w338-w51.

28. Usha Manjunath, Bhimaraya A. Metri, Shalini Ramachandran, Quality management in a healthcare organisation: a case of South Indian hospital. The TQM Mag, 2007;19(2):129-39.

29. Das, Jishnu, Jeffrey Hammer, and Kenneth Leonard. The Quality of Medical Advice in Low-Income Countries. J Econ Perspect 2008;22(2):93-114.

30. Enakshi Ganguly, PR Deshmukh, and BS Garg. Quality Assessment of Private Practitioners in Rural Wardha, Maharashtra. Indian J Community Med 2008;33(1):35-7.

31. Manjunath, Usha. Core Issues in Defining Healthcare Quality. ICFAI J Serv Marketing 2008;6(4):72-8.

32. Hirschhorn LR, Ramaswamy R, Devnani M, Wandersman A, Simpson LA, Garcia-Elorrio E. Research versus practice in quality improvement? Understanding how we can bridge the gap. Int J Qual Health Care 2018;30(suppl_1):24-8.

33. Rao KD, Peters DH, Bandeen-Roche K. Towards patientcentered health services in India--a scale to measure patient perceptions of quality. Int J Qual Health Care 2006;18(6):41421.

34. Narang R. Measuring perceived quality of measuring quality health care services in India. Int J Health Care Qual Assur 2010;23:171-86.

35. Bhanderi MN, Kannan S. Untreated reproductive morbidities among ever married women of slums of Rajkot City, Gujarat: the role of class, distance, provider attitudes, and perceived quality of care. J Urban Health 2010;87(2):254-63.

36. Puri N, Gupta A, Aggarwal AK, Kaushal V. Outpatient satisfaction and quality of health care in North Indian medical institute. Int J Health Care Qual Assur 2012;25(8):682-97.

37. Kondasani RK, Panda RK. Customer perceived service quality, satisfaction and loyalty in Indian private healthcare. Int $J$ Health Care Qual Assur 2015;28(5):452-67.

38. Pai YP, Chary ST. Measuring patient-perceived hospital service quality: a conceptual framework. Int J Health Care Qual Assur 2016;18;29(3):300-23.

39. Lee ES, Vedanthan R, Jeemon P, Kamano JH, Kudesia P, Rajan V, Engelgau M, Moran AE. Quality Improvement for Cardiovascular Disease Care in Low- and Middle-Income Countries: A Systematic Review. PLoS One 2016;11(6):e0157036.

40. Agarwal A, Singh MR. Service Quality and Patient Satisfaction: An Exploratory Study of Pathology Laboratories in Jaipur. Hosp Top 2016;94(2):23-32.

41. Pai YP, Chary ST, Pai RY. Patient-perceived hospital service quality: an empirical assessment. Int J Health Care Qual Assur 201812;31(1):76-91.

42. Yasri S, Wiwanitkit V, Hercos BVS(3), Berezovsky A. Quality of the ophthalmological service and satisfaction with the public healthcare system. Arq Bras Oftalmol 2018;81(3):262-4.

43. Mayuri Duggirala, Chandrasekharan Rajendran, R.N. Anantharaman. Patient-perceived dimensions of total quality service in healthcare. Benchmarking: An Int J 2008;15:5:56083.

44. Hardeep Chahal. Predicting Patient Loyalty and Service Quality Relationship: A Case Study of Civil Hospital, Ahmedabad, India. Vision: J Business Perspect 2008;12(4):455.

45. Mufti Samina, Qadri GJ, SA Tabish, Mufti Samiya, and R Riyaz. Patient's Perception of Nursing Care at a Large 
Teaching Hospital in India. Int J Health Sci (Qassim) 2008;2(2):92-100.

46. Basu D, Bhattacharya S, Mahajan A, Ramanan VR, Chandy M. Sterilization indicators in central sterile supply department: quality assurance and cost implications. Infect Control Hosp Epidemiol 2015;36(4):484-6.

47. Das J, Mohpal A. Socioeconomic Status and Quality of Care In Rural India: New Evidence From Provider And Household Surveys. Health Aff (Millwood) 2016;35(10):1764-73.

48. Morton M, Nagpal S, Sadanandan R, Bauhoff S. India's Largest Hospital Insurance Program Faces Challenges In Using Claims Data To Measure Quality. Health Aff (Millwood) 2016;35(10):1792-9.

49. Lora A, Lesage A, Pathare S, Levav I. Information for mental health systems: an instrument for policy-making and system service quality. Epidemiol Psychiatr Sci 2017;26(4):383-94.

50. Dehury RK \& Samal J. "Exit exams" for medical graduates: a guarantee of quality? Indian J Med Ethics 2017;2(3):190-3.

51. Parikh, Chirag R, Karnad, Dilip R. Quality, cost, and outcome of intensive care in a public hospital in Bombay, India. Crit Care Med 1999;27(9):1754-9.

52. M. Palani Natha Raja, S.G. Deshmukh, Subhash Wadhwa. Quality award dimensions: a strategic instrument for measuring health service quality. Int J Health Care Qual Assurance, 1988;20(5):363-78.

53. Louise AnneHultona Zoë Matthewsb Robert William Stones. Applying a framework for assessing the quality of maternal health services in urban India. Socl Sci Med 2007;64(10)208395.

54. Nandraj, Anagha Khot, Sumita Menon and Ruairí Brugha. A stakeholder approach towards hospital accreditation in India. UK Health Policy And Planning;2016 (Suppl 2):70-9.

55. Azam M, Rahman Z, Talib F, Singh KJ. A critical study of quality parameters in health care establishment: developing an integrated quality model. Int J Health Care Qual Assur 2012;25(5):387-402.

56. Mensah Abrampah N, Syed SB, Hirschhorn LR, Nambiar B, Iqbal U, Garcia-Elorrio E, Chattu VK, Devnani M, Kelley E. Quality improvement and emerging global health priorities. Int J Qual Health Care 2018;30(suppl_1):5-9.

57. Mekoth N, George BP, Dalvi V, Rajanala N, Nizomadinov K. Service quality in the public sector hospitals: a study in India. Hosp Top 2012;90(1):16-22.

58. Panda RK, Kondasani RKR. Customers' Precedence for Service Quality Dimensions in Indian Private Healthcare Setting: A Ridit Approach. Hosp Top 2017;95(4):90-9.

59. Assija V, Singh A, Sharma V. Coverage and quality of immunization services in rural Chandigarh. Indian Pediatr 2012;49(7):565-7.

60. Shah S, Desai N, Shah S, Pathare S, Chauhan A, Sharma E. Impact of Quality Rights Gujarat program on dropout rate of patients visiting outpatient psychiatry department of tertiary care hospital. Asian J Psychiatr 2017;28:4-8.

61. Maloney SI, Siahpush M, Dinkel D, Farazi PA, Jose J, Dutta R. Nurse and physician reflections on the application of a quality standards training program to reduce maternal mortality. Midwifery 2018;66:155-60.

62. Dhadwal D, Bhardwaj A, Gupta A, Sharma S, Parashar A, Thakur A, Mahajan A, Chander V, Sood A. Role of Intensive Training in Strengthening the Skills of HIV Counselors for Imparting Quality ICTC Services. Indian J Community Med 2009;34(3):252-4.

63. Ganju SA, Sharma NL, Kanga A. Towards quality improvement: Training and supportive supervision in STI control programme, Himachal Pradesh. Indian Dermatol Online J 2012;3(3):221-2.

64. Das J, Holla A, Das V, Mohanan M, Tabak D, Chan B. In urban and rural India, a standardized patient study showed low levels of provider training and huge quality gaps. Health Aff (Millwood) 2012;31(12):2774-84.

65. Henriksen K, Dayton E. Issues in the design of training for quality and safety. Qual Saf Health Care 2006;15 Suppl 1:i1724.

66. Nayak S, Pradhan JP, Reddy S, Palmer JL, Zhang T, Bruera E. Cancer patients' perception of the quality of communication before and after the implementation of a communication strategy in a regional cancer center in India. J Clin Oncol 2005;23(21):4771-5.

67. Steen R, Mogasale V, Wi T, Singh AK, Das A, Daly C, George B, Neilsen G, Loo V, Dallabetta G. Pursuing scale and quality in STI interventions with sex workers: initial results from Avahan India AIDS Initiative. Sex Transm Infect 2006;82(5):381-5.

How to cite this article: Kamalasanan A, Gurumoorthy S, Subbarayalu AV. Factors influencing the quality of healthcare services in Indian hospitals: A systematic review. J Manag Res Anal 2019;6(2):71-80. 